\title{
Impact of Spouse's Employment on Marital Stability: Evidence from Working Men and Women in Pokhara
}

\author{
Bal Ram Bhattarai \\ Santosh Kumar Gurung \\ Kripa Kunwar
}

\begin{abstract}
This study investigates the impact of employment on marital stability of working men and women. The objectives of research were to identify the demographic and employment characteristics of spouses, to examine the relationship between spouse's employment and marital stability and to analyze factors affecting marital stability. The study has employed descriptive as well as analytical research design. The study is based on primary data collected in Pokhara. The results of the study illustrates that there exits significant differences on mean scores of discuss on relatives, spend leisure, interaction with children, prepare family budget, intimate conversation and share information items by employment type. The results also indicate that in general the satisfaction from marital life is same across employment type but employment of spouse in government job leads to higher affection and commitment. In this connection the study mainly focuses on spouse's employment and marital stability.
\end{abstract}

Keywords: Marital stability, employment, working couples, marital life satisfaction.

\section{Introduction}

Marriage and established family life are the unique qualities of human being, which makes them to be an integral element of social life. It's a union in which two individuals from different background and personality traits interact and cohabit together for cause of establishing a family. As it's an interaction and mutual understanding between two unique personalities, there are chances of having conflict and adjustment problems. Marriage is the primary source of individual happiness and meaning in life. These fulfillment, happiness and positive development will be possible only when the relationship between couples is coherent and satisfactory. Due to the influx of women into the paid workforce in the last half-century, the balance of family dynamics has shifted significantly. For the couple particularly, the impact of both spouses working increases the number of stressors in their marital relationship.Family can be widely thought of as a social union which requires certain activities (i.e., tasks) to be performed. Especially when both spouses are employed, the process of allocation of individuals to these activities may require spouses to negotiate (Scanzoni, 1982), which can be an important source of conflict within marriage. In that case, employment and earnings can be important resources which give relative bargaining power to each spouse in these negotiations (Lundberg \&Pollak, 1993). More specially, a wife with more resources may seek more egalitarian roles in marriage, which can lead to marital conflict if her husband resist for the continuation of status quo in gendered roles. If there is a gender-normative role distribution in the family (which assigns housework to the wife and market work to the husband) as role specialization perspective assumes, then alteration of these roles may upset marital quality in two ways 
(Becker, 1981; Op-penheimer, 1997). First, it may create a hostile family environment by introducing status competition among spouses. Second, it can undermine the gains from being married by reducing the housework done by wives and other family-related services husbands would get from wives who are not working. Both of these are especially relevant for husbands whose role as provider is being challenged. Given women's increasing labor force participation and commensurate rise in their earnings but lagged change in the distribution of household chores, the circumstances are ideal for marital conflict. Women's relative income will increase marital conflict, due to the assumption that wives become more independent as their income increases. The purpose of this study is to examine how marital satisfaction and marital conflict changes over time for husbands and for wives, with a focus on the influence of gender roles in the prediction of husbands' and wives' marital satisfaction and marital conflict. Given the extant literature reviewed, there is a need to understand the conditions leading to a marital relationship of dissatisfaction and which factors can be used to predict the maintenance of positive, satisfying relationships.

\subsection{Review of Literature}

Rataj and Matysiak (2012) investigated on "Which family model makes couples more happy - dual earner or male breadwinner?” the effects of men's and women's employment on their spouses' subjective well-being in Poland. The study used panel data techniques that allow researcher to account for selection of intrinsically happy individuals into malebreadwinner or dual earner models. The study found that women's employment has positive impact on women's well-being, but reduces the happiness of their husbands. These findings suggest that the sex-role specialisation model is rooted in the perception of Polish men. It turns out that husband's involvement in the labour market does not affect the subjective well-being of wives. Among men, however, researchers observed a clearly detrimental effect of their wives employment on husbands' psychological well-being. Thus men in Poland are satisfied with a male breadwinner family model - they are happier if they work and they prefer to have non-working wives.

Matysiak, Styrc and Vignoli (2013) contributes on "Job and stable marriage: Does context matter?"to the recent discussion on the role of the context for the relationship between women's employment and marital stability. This literature presupposed that women's employment is more likely to stabilise marriages if women's employment is state supported and socially accepted. To this end researchers compare Italy and Poland - two countries which share a number of similarities, like strong attachment to family and Catholic values and delayed diffusion of new family behaviours, and at the same time display key differences with regard to women's labour force participation, household living standards and gender roles. Using recent representative surveys, the Italian Multipurpose Household Survey and the Polish Generations and Gender Survey, researchers estimate a joint multiprocess model of marital disruption and paid work participation which allows us to account for the common unobserved factors affecting the two processes and to estimate an unbiased effect of employment on marital disruption.

Cooke, et al. (2013) find on "Labor and Love: Wives' Employment and Divorce Risk in its Socio-Political Context" that how social policy affects marital stability in comparison with macro and micro effects of wives' employment on divorce risk in 11 Western countries. Correlations among 1990s aggregate data on marriage, divorce, and wives' employment rates, along with attitudinal and social policy information, seem to support specialization hypotheses that divorce rates are higher where more wives are employed and where 
policies support that employment. This is an ecological fallacy, however, because of the nature of the changes in specific countries. At the micro level, we harmonize national longitudinal data on the most recent cohort of wives marrying for the first time and find that the stabilizing effects of a gendered division of labor have ebbed. In the United States with its lack of policy support, a wife's employment still significantly increases the risk of divorce. A wife's employment has no significant effect on divorce risk in Australia, Flanders, France, Germany, Italy, the Netherlands, and the United Kingdom. In Finland, Norway, and Sweden, wives' employment predicts a significantly lower risk of divorce when compared with wives who are out of the labor force. The results indicate that greater policy support for equality reduces and may even reverse the relative divorce risk associated with a wife's employment.

Edsel (2012) for completion of the study researchers used the data of the World Values Survey to answer the question: "Who is happier: the housewife or the working wife?" Relative to the unpaid work of the housewife, paid work was defined in three categories, namely: full-time, part-time, or self-employment. In general, the paper found no clear evidence of a difference in the happiness between the housewife and the working wife. What the paper found instead was some evidence that if ever a disparity in the happiness between the housewife and the working wife existed it might be associated with culture and social context. What might apply to the working wife in West Europe and North America need not apply in the other areas, etc. Certainly, there is a lot of variation from the results across the emerging country groupings. For instance, the results pointed out that paid work regardless of status may be perceived as a "good" in some areas but a "bad" in others. More specifically, the differences in the happiness between the housewife and working wife might be more the outcomes of habit produced by culture and social norms.

Cooke and Gash (2010) find on "Wives' Part-time Employment and Marital Stability in Great Britain, West Germany and the United States," effects of wives' employment on marital stability vary across the countries. In West Germany with its high-quality part-time employment, couples where the wife works part time are significantly more stable. In the more liberal British and US labour markets, neither wives' part- nor full-time employment significantly alters divorce risk. In the United States, however, mothers working part time have significantly lower divorce risk. West German and British husbands' unemployment proves more detrimental to marital stability than wives' employment. These results highlight the importance of the socioeconomic context in structuring the optimal employment participation of both partners.

\section{Problems and Objectives}

Wives' employment has long been considered one of the most important determinants of marital instability. The role of women's social and economic independence for marital stability has been of interest for social scientists for several decades in response to growing female labor force participation and marital disruption. Women's role as an employee and breadwinner is a positive change on the gender equity and participation but simultaneously it's having implications on family life, especially in a society like Nepal. Women, who are employed, have to face the problems of dual role and it has influence on marital and family life.Based on the literature review, the specific objectives of the study are to identify the demographic and employment characteristics of spouses, to examine the relationship between spouse's employment and marital stability and to analyze factors affecting marital stability. 


\section{Data and Methods}

The population of the study comprised of all individuals in Pokhara with both husband and wife employed. The study took 232 married employees in different organizations of Pokhara whose spouses too were employed as sample. The study was based on primary data. The structured questionnaire was prepared and respondent administered. The study has employed non probability technique of sampling. The respondents were identified on the basis of researcher's convenience. The study has employed descriptive as well as analytical research design. The socio demographic data is descriptively analyzed and data related to marital stability is analytically interpreted. The study used several statistical tools to analyze the data. Simple descriptive statistics as well as inferential tests was applied to interpret the data. One-way ANOVA, Independent samples t-test, and Chi-square test has been used in the study. The marital stability has been measured on the basis of three major indicators as found through extensive review of the past literature. They are listed below:

\begin{tabular}{|c|ll|}
\hline $\begin{array}{c}\text { Indicators } \\
\text { (Dependent Variable) }\end{array}$ & \multicolumn{1}{|c|}{$\begin{array}{c}\text { Possible Determining Factors } \\
\text { (Independent Variable) }\end{array}$} \\
\hline \multirow{4}{*}{ 1) Number of disagreements between couples } \\
2) Sharing Information \\
3) Intimate Conversation
\end{tabular}




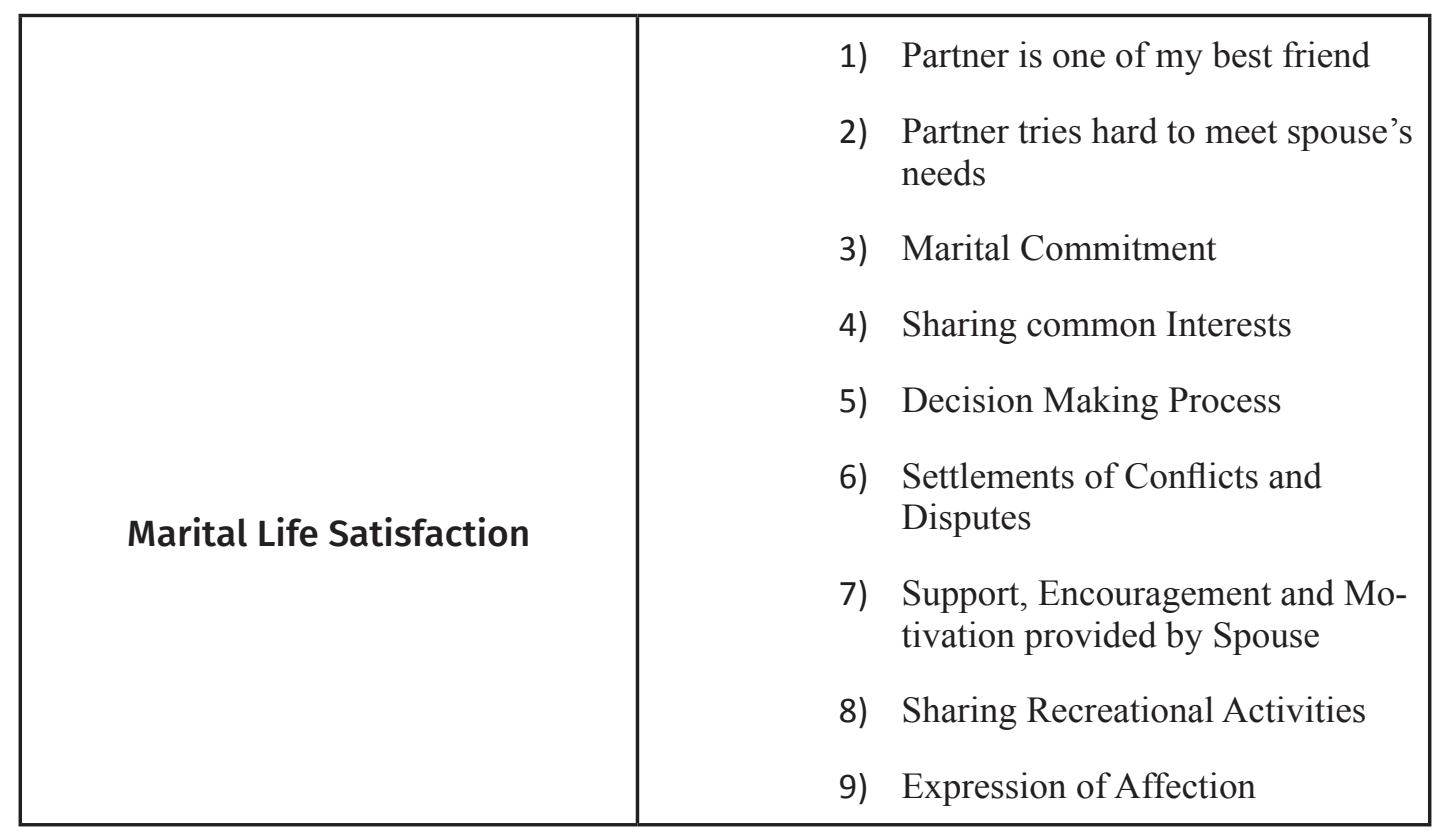

\section{Discussion and Analysis}

Table 1 exhibits that majority (79.3) percent of the respondent were Brahman and 20.7 percent is been shared by other ethnic groups like Chhetri, Gurung, Newar, and Magar. The result also shows that the percent of arranged marriage is higher than in comparison to love marriage. Similarly, 60.3 percent of the respondents belong to nuclear family and 39.7 percent of the respondent stay in joint family. The percent of nuclear family is higher due to the family requirement to move from their home to other places for education and job. The number of children that the employed couple bears is also found less due to busy life, highly expensive education, marriage affairs and marriage durations. Majority $(51.7 \%)$ of the people marry in between the age group of 21-25.This result is affected by the traditional belief of family that the suitable age for a girl to marry is from 21-25.In the same way, 28.4 percent of the respondents' duration of marriage is between $6-10$ years, 25.9 percent of respondents duration is between $11-20$ years, 24.1 percent of respondent duration is between 1-5 years, 11.2 percent of the respondents' marriage duration is above 20 years and only 10.3 percent of the respondents duration of marriage is less than one year. In addition to this 55.2 percent of the respondents are having the marriage age gap of 1-5 years and 31 percent of the respondents' marriage age gap is 5-10 years. The age difference is there in couples due to arrange marriage where family chooses the girl and they prefer to have their daughter-in-law age less than their son's age. 58.6 percent of the respondents have completed their masters' degree and 2.6 percent of the respondents have passed SLC. As the study is concerned with working couples thus, the entire respondent in the study are educated. 
Table 1: Number and percentage distribution of respondents according to their profile

\begin{tabular}{|c|c|c|}
\hline Age & Frequency & Percent \\
\hline $22-26$ & 34 & 14.7 \\
\hline $27-31$ & 50 & 21.6 \\
\hline $32-36$ & 70 & 30.2 \\
\hline $37-41$ & 38 & 16.4 \\
\hline $42+$ & 40 & 17.2 \\
\hline \multicolumn{3}{|l|}{ Sex of Respondent } \\
\hline Male & 120 & 51.7 \\
\hline Female & 112 & 48.3 \\
\hline \multicolumn{3}{|c|}{$\begin{array}{l}\text { Caste/ Ethnicity of the } \\
\text { Respondent }\end{array}$} \\
\hline Brahman & 92 & 79.3 \\
\hline Chhetri & 13 & 11.2 \\
\hline Gurung & 3 & 2.6 \\
\hline Newar & 6 & 5.2 \\
\hline Magar & 2 & 1.7 \\
\hline \multicolumn{3}{|l|}{ Type of Marriage } \\
\hline Arranged marriage & 184 & 79.3 \\
\hline Love marriage & 48 & 20.7 \\
\hline \multicolumn{3}{|l|}{ Type of Family } \\
\hline Joint & 92 & 39.7 \\
\hline Nuclear & 140 & 60.3 \\
\hline \multicolumn{3}{|c|}{ Total number of children } \\
\hline No children at all & 54 & 23.3 \\
\hline 1 & 76 & 32.8 \\
\hline 2 & 100 & 44.1 \\
\hline 3 and above & 2 & .9 \\
\hline \multicolumn{3}{|l|}{ Age at Marriage } \\
\hline Below 20 & 24 & 10.3 \\
\hline $21-25$ & 120 & 51.7 \\
\hline $26-30$ & 74 & 31.9 \\
\hline Above 31 & 14 & 6.0 \\
\hline \multicolumn{3}{|l|}{ Duration of Marriage } \\
\hline Less than 1 year & 24 & 10.3 \\
\hline
\end{tabular}


The Journal of Nepalese Bussiness Studies

\begin{tabular}{|c|c|c|}
\hline $1-5$ year & 56 & 24.1 \\
\hline 6-10 year & 66 & 28.4 \\
\hline 11-20 year & 60 & 25.9 \\
\hline Above 20 year & 26 & 11.2 \\
\hline \multicolumn{3}{|l|}{ Age Gap } \\
\hline Similar age & 10 & 4.3 \\
\hline Less than 1 year & 18 & 7.8 \\
\hline $1-5$ year & 128 & 55.2 \\
\hline 5-10 year & 72 & 31.0 \\
\hline Above 10 year & 4 & 1.7 \\
\hline \multicolumn{3}{|l|}{ Educational Level } \\
\hline SLC & 6 & 2.6 \\
\hline $10+2$ & 40 & 17.2 \\
\hline Bachelors & 36 & 15.5 \\
\hline Masters & 136 & 58.6 \\
\hline Mphil or MS & 12 & 5.2 \\
\hline Doctorate & 2 & .9 \\
\hline Work before Marriage & Frequency & Percent \\
\hline Yes & 174 & 75.0 \\
\hline No & 58 & 25.0 \\
\hline \multicolumn{3}{|l|}{$\begin{array}{l}\text { If yes, how long have you } \\
\text { worked before your marriage? }\end{array}$} \\
\hline Less than 1 year & 24 & 13.8 \\
\hline $1-5$ years & 100 & 57.5 \\
\hline 6-10 years & 36 & 20.7 \\
\hline Above 10 years & 14 & 8.0 \\
\hline \multicolumn{3}{|l|}{ Monthly Income } \\
\hline Below 10000 & 12 & 5.2 \\
\hline $10001-20000$ & 72 & 31.0 \\
\hline 20001-30000 & 90 & 38.8 \\
\hline $30001-40000$ & 26 & 11.2 \\
\hline $40001-50000$ & 24 & 10.3 \\
\hline Above 50001 & 8 & 3.4 \\
\hline \multicolumn{3}{|l|}{$\begin{array}{l}\text { Has your spouse worked } \\
\text { before marriage? }\end{array}$} \\
\hline Yes & 170 & 73.3 \\
\hline No & 62 & 26.7 \\
\hline
\end{tabular}




\begin{tabular}{|l|l|l|}
\hline $\begin{array}{l}\text { If yes, how long has your } \\
\text { spouse worked before } \\
\text { marriage? }\end{array}$ & & \\
\hline Less than 1 year & 20 & 11.8 \\
\hline 1-5 year & 112 & 65.9 \\
\hline 6-10 year & 30 & 17.6 \\
\hline Above 10 year & 8 & 4.7 \\
\hline $\begin{array}{l}\text { Your spouse's } \\
\text { educational level }\end{array}$ & & \\
\hline SLC & 8 & 3.4 \\
\hline $10+2$ & 42 & 18.1 \\
\hline Bachelors & 38 & 16.4 \\
\hline Masters & 132 & 56.9 \\
\hline Mphil or MS & 10 & 4.3 \\
\hline Doctorate & 2 & .9 \\
\hline $\begin{array}{l}\text { Nature of organization } \\
\text { your spouse work }\end{array}$ & & \\
\hline Financial institution & 40 & 17.2 \\
\hline Educational institution & 128 & 55.2 \\
\hline Government institution & 10 & 4.3 \\
\hline Corporations & 4 & 1.7 \\
\hline NGOs/INGOs & 14 & 6.0 \\
\hline Private company & 20 & 8.6 \\
\hline Other & 4 & 1.7 \\
\hline Health sector & 12 & 5.2 \\
\hline $\begin{array}{l}\text { Your spouse's monthly } \\
\text { income }\end{array}$ & & 31.0 \\
\hline Below 10000 & 12 & 34.5 \\
\hline $10001-20000$ & 80 & 15.5 \\
\hline 20001-30000 & 36 & 4.3 \\
\hline $30001-40000$ & 10 & \\
\hline $40001-50000$ & & 5.2 \\
\hline Above 50001 & & \\
\hline & & \\
\hline
\end{tabular}

The result indicates 57.5 percent of the respondents' duration of work before marriage fall under the group of 1-5 years and 20.7 percent of the respondents working before marriage fall under the group of 6-10 years. The result shows that majority of the males were employed before their marriage.53.4 percent of the respondents work in educational institution and 20.7 percent respondents in financial institution. It is so because majority of the respondents are highly educated. So, couples are employed either in educational or financial institution. 38.8 percent of the respondents' monthly income is between rupees 
20,000 to 30,000 and 31.0 percent of the respondents monthly income is between rupees 10,000 to 20,000 . The income pattern of the respondents is better. Likewise 65.9 percent of the respondents spouse has worked for 1-5 years before marriage and 17.6 percent of the respondents spouse has worked for 6-10 years before marriage. This result is because of marriage age difference and duration of marriage of the respondents.

Figure 1 below exhibits the mean scores of the 9 items used to measure sub-construct intimacy between the working couples. The questions structured in five point Likert scale $(1=$ Everyday, 2 = Very often, 3 = Fairly many times, $4=$ occasionally and $5=$ never $)$ ask the respondents the frequency of the 9 activities given in vertical axis of the following figure. Lower response values indicate higher intimacy between couples and vice-versa. The following mean scores are average response of 232 sample respondents.

Figure 1: Mean Scores of intimacy

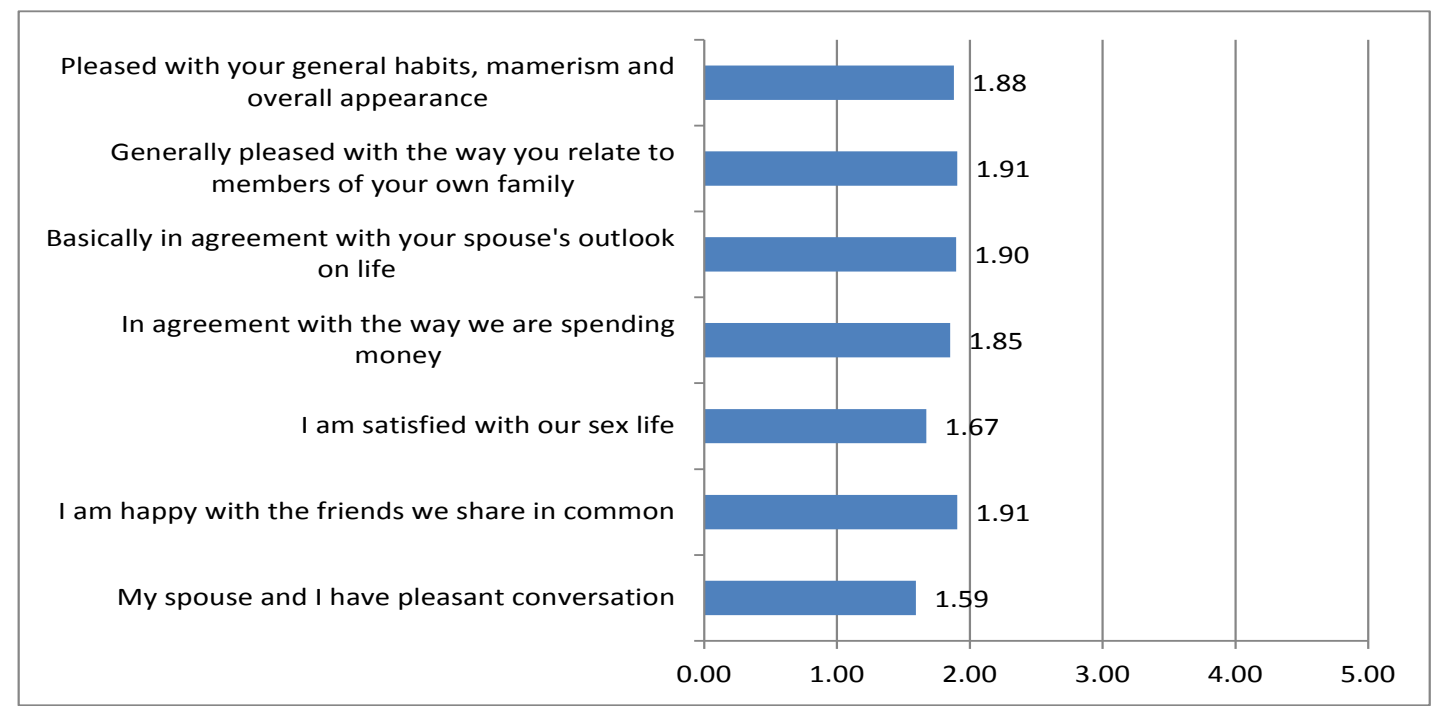

The above graph reveals that working couples of Pokhara have higher degree of interaction with children, intimate conversation, and income sharing. The number of disagreements between couples is low. However, the couples get less time to spend leisure together. All average item scores indicate presence of intimacy among the working couples.

Figure 2 below illustrates the mean scores of affection and happiness which are measured on 7 item 5-point Likert scale ( 1 = Very happy, $2=$ Happy, $3=$ Somewhat happy, $4=$ Neither happy nor unhappy and $5=$ unhappy). All item means reveal that the level of affection between couples and marital life happiness of the working couples is high.

The indicators of affection like pleasant conversation between couples, sex-life satisfaction and personality congruence show working couples have affectionate relationship. The working couples are happy with financial management, family life and their social circle. Overall, the above findings reveal that the working couples are happy with their married life.

Marital life satisfaction in figure 3 is measured with 9 item 5 -point Likert scale $(1=$ Very satisfied, 2 = Satisfied, $3=$ Somewhat satisfied, $4=$ Somewhat dissatisfied, and $5=$ Dissatisfied). The average scores of 232 sample respondents is shown in figure 3 given 
below. All the mean scores are below 2.3 which depicts that working couples in Pokhara are satisfied with their married life.

\section{Figure 2: Mean scores of affection and happiness}

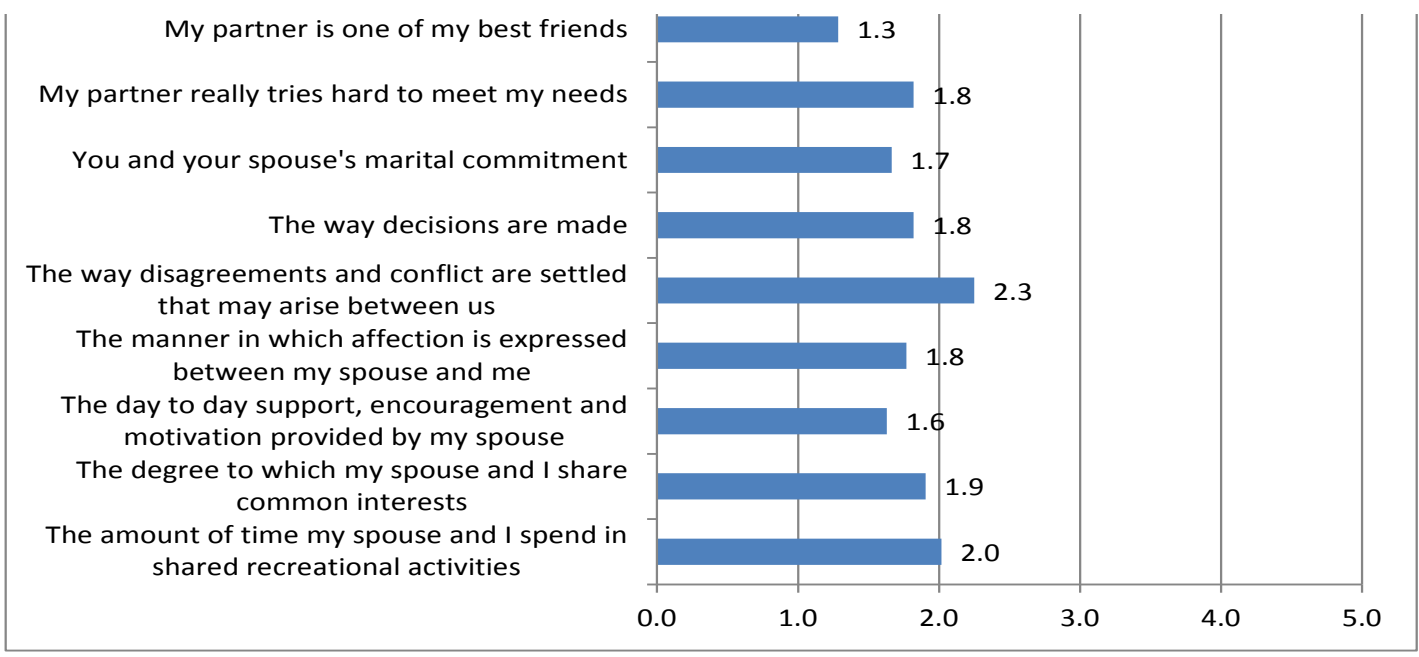

Figure 3: Mean scores of marital life satisfaction

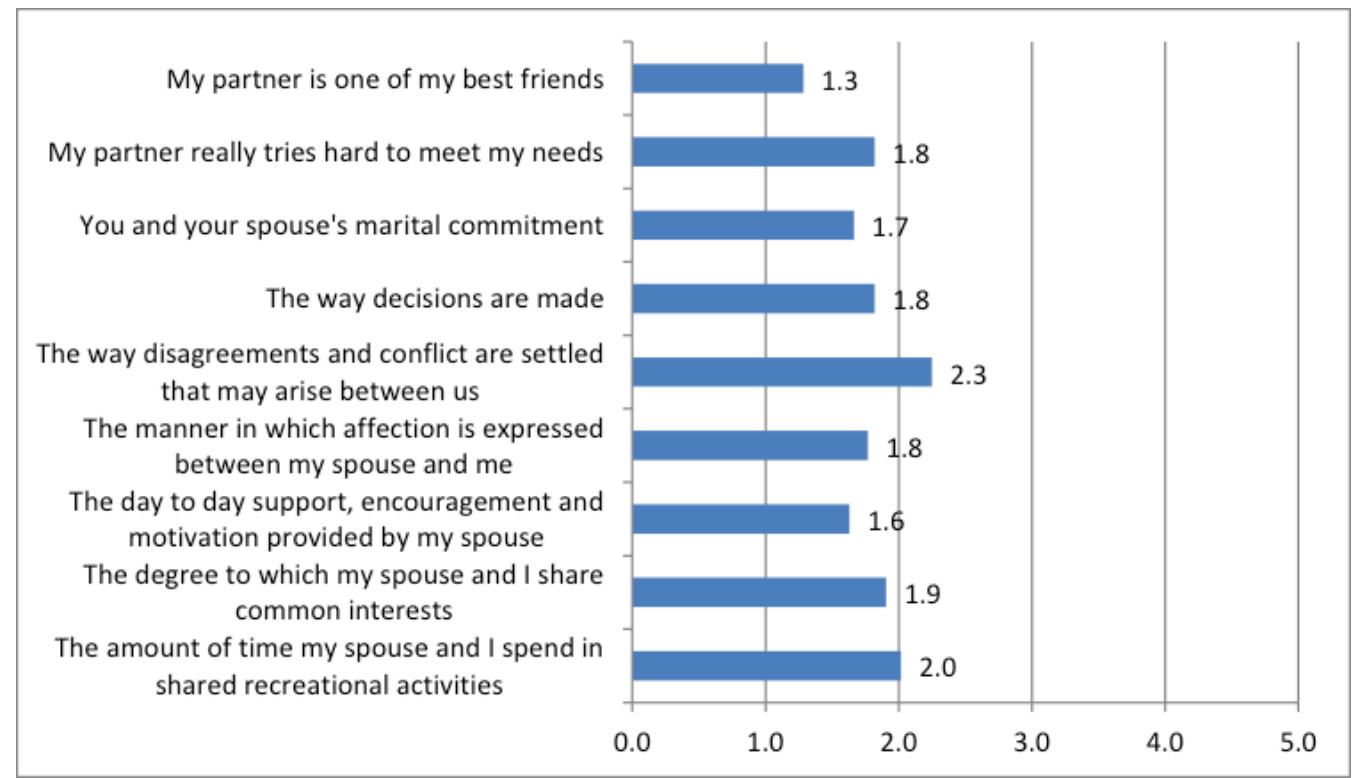

The satisfaction is higher in indicators like friendly relation, support \& motivation, partner commitment, need satisfaction, decision making process, expression of affection and sharing of common interests. The degree of satisfaction is relatively lower in time for shared recreation and conflict resolution.

\subsection{Employment Status and Marital Stability}

Table 2 exhibits the output of one-way ANOVA test used to analyze differences in mean scores of marital stability indicators by employment type of spouse. It is hypothesized 
that marital stability is different by type of organization spouses are employed in. The government sector employment, private sector employment and self-employed (business) provide different working conditions and may have influence in the marital life of the working couples. The one-way ANOVA test is conducted using three factors (government employment, private sector employment and business).

The results of the test reveal that there exits significant differences on mean scores of discuss on relatives, spend leisure, interaction with children, prepare family budget, intimate conversation and share information items by employment type. The null hypotheses of no differences in mean scores of these items by employment type has been rejected at 5 percent level of significance. Comparison of mean scores of government, private sector employment and business indicate that private sector employed couples have higher frequency of spending leisure time together, discuss on relatives, and information sharing about future plans. Similarly, couples engaged in business have higher frequency of interaction with children, sharing income and intimate conversation. The analysis of significant value of F-stat and comparison of different mean scores of each item show that couples with business have highest level of intimacy. Private sector employment is seen to result in higher intimacy among married couples than government sector employment.

Table 2: Test of differences in marital stability indicators by employment type

\begin{tabular}{|l|c|c|c|c|c|l|}
\hline Intimacy Items & $\begin{array}{l}\text { Aggre- } \\
\text { gate }\end{array}$ & Govt. & $\begin{array}{l}\text { Prvate } \\
\text { Sector }\end{array}$ & Business & F-stat & Sig. \\
\hline Discuss on relatives & 2.61 & 2.82 & 2.38 & 2.60 & $3.818^{*}$ & 0.023 \\
\hline Spend leisure or free time & 2.48 & 2.68 & 2.22 & 2.70 & $5.311^{*}$ & 0.006 \\
\hline Interaction with children & 1.70 & 1.61 & 1.94 & 1.00 & $6.947^{*}$ & 0.001 \\
\hline Prepare family budget & 2.49 & 2.39 & 2.68 & 2.10 & $3.643^{*}$ & 0.028 \\
\hline Sharing income & 2.03 & 1.96 & 2.10 & 2.00 & 0.477 & 0.621 \\
\hline Sharing household activities & 2.13 & 2.09 & 2.24 & 1.80 & 1.389 & 0.251 \\
\hline Intimate conversation & 1.86 & 1.75 & 2.06 & 1.50 & $4.299^{*}$ & 0.015 \\
\hline $\begin{array}{l}\text { Share information about future } \\
\text { plans }\end{array}$ & 2.12 & 2.10 & 2.05 & 2.60 & $2.493^{*}$ & 0.085 \\
\hline $\begin{array}{l}\text { The number of disagreements } \\
\text { between my spouse and me }\end{array}$ & 3.50 & 3.53 & 3.49 & 3.40 & 0.143 & 0.867 \\
\hline \multicolumn{1}{|c|}{ Affection and Happiness Items } & & & \\
\hline $\begin{array}{l}\text { My spouse and I have pleasant } \\
\text { conversation }\end{array}$ & 1.59 & 1.55 & 1.65 & 1.50 & 0.908 & 0.405 \\
\hline $\begin{array}{l}\text { I am happy with the friends we } \\
\text { share in common }\end{array}$ & 1.91 & 1.80 & 2.02 & 1.80 & $3.146^{*}$ & 0.045 \\
\hline I am satisfied with our sex life & 1.67 & 1.59 & 1.76 & 1.60 & 1.336 & 0.265 \\
\hline $\begin{array}{l}\text { In agreement with the way we are } \\
\text { spending money }\end{array}$ & 1.85 & 1.76 & 1.93 & 1.90 & 1.599 & 0.204 \\
\hline
\end{tabular}


Impact of Spouse's Employment on Marital Stability: Evidence from Working ...

\begin{tabular}{|c|c|c|c|c|c|c|}
\hline $\begin{array}{l}\text { Basically in agreement with your } \\
\text { spouse's outlook on life }\end{array}$ & 1.90 & 1.86 & 1.95 & 1.80 & 0.503 & 0.606 \\
\hline $\begin{array}{l}\text { Generally pleased with the way } \\
\text { you relate to members of your } \\
\text { own family }\end{array}$ & 1.91 & 2.02 & 1.82 & 1.80 & 1.933 & 0.147 \\
\hline $\begin{array}{l}\text { Pleased with your general habits, } \\
\text { mannerism and overall appear- } \\
\text { ance }\end{array}$ & 1.88 & 1.92 & 1.82 & 2.00 & 1.015 & 0.364 \\
\hline \multicolumn{7}{|c|}{ Marital Life Satisfaction Items } \\
\hline $\begin{array}{l}\text { The amount of time my spouse } \\
\text { and I spend in shared recreation- } \\
\text { al activities }\end{array}$ & 2.02 & 2.08 & 1.95 & 2.10 & 0.922 & 0.399 \\
\hline $\begin{array}{l}\text { The degree to which my spouse } \\
\text { and I share common interests }\end{array}$ & 1.91 & 1.86 & 1.96 & 1.80 & 0.777 & 0.461 \\
\hline $\begin{array}{l}\text { The day to day support, encour- } \\
\text { agement and motivation provided } \\
\text { by my spouse }\end{array}$ & 1.63 & 1.59 & 1.65 & 1.70 & 0.418 & 0.659 \\
\hline $\begin{array}{l}\text { The manner in which affection } \\
\text { is expressed between my spouse } \\
\text { and me }\end{array}$ & 1.77 & 1.61 & 1.93 & 1.70 & $5.250 *$ & 0.006 \\
\hline $\begin{array}{l}\text { The way disagreements and con- } \\
\text { flict are settled that may arise be- } \\
\text { tween us }\end{array}$ & 2.25 & 2.16 & 2.29 & 2.50 & 1.294 & 0.276 \\
\hline The way decisions are made & 1.82 & 1.84 & 1.76 & 2.00 & 1.348 & 0.262 \\
\hline $\begin{array}{l}\text { You and your spouse's marital } \\
\text { commitment }\end{array}$ & 1.66 & 1.49 & 1.75 & 2.10 & $8.368 *$ & 0.000 \\
\hline $\begin{array}{l}\text { My partner really tries hard to } \\
\text { meet my needs }\end{array}$ & 1.82 & 1.73 & 1.93 & 1.70 & 1.961 & 0.143 \\
\hline $\begin{array}{l}\text { My partner is one of my best } \\
\text { friends }\end{array}$ & 1.28 & 1.29 & 1.27 & 1.30 & 0.050 & 0.951 \\
\hline No of Observations (N) & 232 & 102 & 110 & 20 & & \\
\hline
\end{tabular}

For items measuring affection and happiness, F-value of only one item (Friendship circle) is significant. Hence, the result of the analysis finds that there is no significant difference in affection and happiness by employment type. The type of organization where spouse is employed doesn't affect the affection and happiness of the married and working couples.

For marital life satisfaction items, only expression of affection and commitment in relationship are found to be significant. The mean scores of government job are lower for those two items. Hence, the results indicate that in general the satisfaction from marital life is same across employment type but employment of spouse in government job leads to higher affection and commitment. 


\section{Summary and Conclusion}

The Likert scale was used 5 points $(1=$ Very high marital stability and $5=$ Very low marital stability) to measure the concept of marital stability. The mean of averages of all 25 scale items is 1.991 which indicates that the degree of marital stability in working couples in Pokhara is high. The range, min-max ratio and variance which are the measure of interitem variability in perceptions of working couples towards marital stability are relatively low. It means that the differences in degree of marital stability measured among different dimensions are low. Hence, the above findings reveal that marital stability in working couples of Pokhara is high.

The indicators of affection like pleasant conversation between couples, sex-life satisfaction and personality congruence show working couples have affectionate relationship. The working couples are happy with financial management, family life and their social circle. Overall, the above findings reveal that the working couples are happy with their married life.

It was also concluded that marital satisfaction is higher in indicators like friendly relation, support \& motivation, partner commitment, need satisfaction, decision making process, expression of affection and sharing of common interests. The degree of satisfaction is relatively lower in time for shared recreation and conflict resolution.

The study exhibited the output of one-way ANOVA test used to analyze differences in mean scores of marital stability indicators by employment type of spouse. It is hypothesized that marital stability is different by type of organization spouses are employed in. The government sector employment, private sector employment and self-employed (business) provide different working conditions and may have influence in the marital life of the working couples. The one-way ANOVA test is conducted using three factors (government employment, private sector employment and business).The results of the test reveal that there exits significant differences on mean scores of discuss on relatives, spend leisure, interaction with children, prepare family budget, intimate conversation and share information items by employment type. Comparison of mean scores of government, private sector employment and business indicate that private sector employed couples have higher frequency of spending leisure time together, discuss on relatives, and information sharing about future plans. Similarly, couples engaged in business have higher frequency of interaction with children, sharing income and intimate conversation. The analysis of significant value of F-stat and comparison of different mean scores of each item show that couples with business have highest level of intimacy. Private sector employment is seen to result in higher intimacy among married couples than government sector employment.

For items measuring affection and happiness, F-value of only one item (Friendship circle) is significant. Hence, the result of the analysis finds that there is no significant difference in affection and happiness by employment type. The type of organization where spouse is employed doesn't affect the affection and happiness of the married and working couples.

For marital life satisfaction items, only expression of affection and commitment in relationship are found to be significant. 


\section{BIBLOGRAPHY}

Becker, G. S. (1981). A Treatise on the family. Harvard University Press .

Becker, G. S., Landes, E. M., \& Michael, R. T. (1977). An economic analysis of marital instability. Journal of Political Economy, 1141-1187.

Cooke, L. P., \& Gash, V. (2010). Wives' part-time employment and marital stability in great britain, west germany and the United States. Sociology .1091-1108.

Cooke, L. P., Erola, J., Evertsson, M., Gahler, M., Ha rkonen, J., Hewitt, B., et al. (2013). Labor and love: Wives' employment and divorce risk in its socio-political context. Social Politics .

Edsel, B. J. (2012). Who is happier: The housewife or working wife? Munich Personal RePEC Archive .

Greene, W. H., \& Quester, A. O. (1982). Divorce risk and wives' labor supply behavior. Social Science Quarterly, 63, 16-27.

Lundberg, S., \& Pollak, R. (1993). Separate spheres bargaining and the marriage market. Journal of Political Economy 101(6), 988-1010.

Oppenheimer, V. K. (1997). Women's employment and the gain to marriage: the specialization and trading model. Annual Review of Sociology, 431-453.

Rataj, A. B., \& Matysiak, A. (2012). Which family model makes couples more happy -dual earner or male breadwinner?

Scanzoni, J. T. (1972). Sexual bargaining: Power politics in the American marriage. Chicago: University of Chicago Press .

Schoen, R., Astone, N. M., Kim, Y. J., Rothert, K., \& Standish, N. J. (2002). Women's employment, marital happiness, and divorce. Social Forces 81, 643-662. 